\title{
PENERAPAN MANAJEMEN PENDIDIKAN DALAM MEWUJUDKAN VISI SEKOLAH (STUDI DI SMP NEGERI 1 SALOMEKKO)
}

\begin{abstract}
Saril $^{1}$
Abstract: Implementation of Education Management in Achieving Vision The school implements by conducting activities in each work unit so that it can be organized towards the same goal of allocating resources to develop and implement and sekolmpok people who are directed to work together for planning, organizing implementation and supervision. Facilitate the learning process, create program activities in schools, develop plans and quality improvement programs, evaluate the implementation, apply the system in accordance with the expectations of the school so that the regular learning process regularly with effective and efficient. The independence of professionalism to schools merupankan one factor to be able to encourage schools in menjujdukan vision and mission. Therefore, in applying a curriculum required by a strict, professional principal with strong management and leadership skills to be able to take decisions and initiatives to improve the quality of the school. Implementation of education management has been able to run well because seen from the vision and mission of the school is quite applicable by many teachers and students also can apply all that has terpapan in the future.
\end{abstract}

Keywords: Management of Islamic Education and vision

\section{Pendahuluan}

Tujuan pendidikan Negara Indonesia yang tertuang dalam UndangUndang Republik Indonesia Nomor 20 Tahun 2003 tentang Sistem Pendidikan Nasional adalah usaha sadar dan terencana untuk mewujudkan suasana belajar dan proses pembelajaran agar peserta didik secara aktif mengembangkan potensi dirinya untuk memiliki kekuatan spritual

\footnotetext{
${ }^{1}$ Fakultas Tarbiyah, Institut Agama Islam Negeri (IAIN) Bone
} 
keagamaan, pengendalian diri, kepribadian, kecerdasan, akhlak mulia serta keterampilan yang diperlukan dirinya masyarakat bangsa dan negara. ${ }^{2}$ Agar kegiatan pendidikan tersebut terencana dengan baik maka dibutuhkan kurikulum pendidikan.

Sekolah sebagai lembaga pendidikan tentu memiliki posisi yang krusial dan determinatif bagi peningkatan kualitas pendidikan. Oleh karena salah satu kendala utama peningkatan kualitas tersebut terletak pada proses pengelolaan sekolah dan pengelolaan pembelajaran yang tidak berkembang secara profesional. Dari argumentasi obyektif inilah sehingga tidak mengherankan jika sekolah menjadi obyek sasaran pertanyaan masyarakat. Oleh karena itu, sekolah sebagai tempat berlangsungnya proses pendidikan, penting ditingkatkan kinerja dan produk ide kreatif yang menyesuaikan diri terhadap perkembangan zaman yang ada sehingga dapat menciptakan keberhasilan dunia pendidikan yang didambakan, dengan berbagai upaya peningkatan mutu pengelolaan dan mutu hasil pembelajarannya. ${ }^{3}$

Manajemen didefinisikan sebagai kegiatan mengelola berbagai sumber daya dengan cara bekerjasama dengan orang lain melalui proses tertentu untuk mencapai tujuan organisasi secara efektif dan efisien. ${ }^{4}$

${ }^{2}$ Republik Indonesia Undang-undang Nomor 20 Tahun 2003 tentang Sistem Pendidikan Nasional (Cet. I; Jakarta: CV. Eka Jaya, 2003), h. 4

${ }^{3}$ Lihat juga Abd. Rahman Getteng, Pendidikan Islam dalam Pembangunan (Ujung Pandang: Yayasan al-Ahkam, 1997), h.25

${ }^{4}$ Bar Hartani, Manajemen Pendidikan (Cet. I; Yogyakarta: Laksibang Pressindo. 2011), h. 141 
Manajemen pendidikan diartikan sebagai proses pengadaan dan pendayagunaan komponen-komponen yang secara langsung maupun tidak langsung menunjang proses pendidikan untuk mencapai tujuan pendidikan secara efektif dan efisien. Proses-proses yang dilakukan dalam upaya pengadaan dan pendayagunaan, meliputi perencanaan, pengadaan, pengaturan, penggunaan, dan penghapusan. ${ }^{5}$

Berdasarkan observasi awal di SMPN 1 Salomekko, peneliti: menemukan bahwa masih banyak guru menganggap perlu untuk melibatkan bagaimana manajemen pendidikan dalam mewujudkan visi di SMPN 1 Salomekko, menitikberatkan pada manajemen pendidikan dalam pencapain visi sekolah di SMPN 1 Salomekko, Karena visi sekolah merupakan kunci keberhasilan sebuah lembaga pendidikan yang dikelola secara profesional baik berkaitan dengan penyusunan proposal, pelaksanaan, maupun pelaporannya, agar guru senantiasa dapat melakukan perbaikan dari setiap pembelajaran yang dilakukannya agar visi sekolah dapat diwujudkan.

\section{A. Manajemen Pendidikan dan Penerapannya di Sekolah}

\section{Pengertian Manajemen Pendidikan}

Kata "Manajemen" jika kita lacak akar bahasanya ternyata berasal dari kata bahasa latin, yaitu dari kata manun yang berarti tangga,dan agree yang bererti melakukan yang berarti melakukan. Kata-kata sebagaimana

${ }^{5}$ B. Suryosubroto, Manajemen Pendidikan di Sekolah (Cet. II; Jakarta: PT Rineka Cipta, 2010), h. 114 
telah diuraikan, jika digabung menjadi kata kerja "manager "yang artinya menangani. Kata manager ini jika diterjemahkan ke dalam Inggris dalam bentuk kata kerja to manage, dengan kata benda management, dan manager untuk orang yang melakukan kegiatan manajemen. Akhirnya management diterjemahkan ke dalam bahasa Indonesia menjadi manajemen atau pengelolaan.

Secara etimologis manajemen berasal dari kata to manage yang berarti mengurus, mengatur, mengemudikan, mengendalikan, menangani, mengelola, menyelenggarakan, menjalankan, melaksanakan, dan memimpikan. Sedangkan management berasal dari kata mano yang berubah menjadi manus berarti bekerja berkali-kali dengan menggunakan tanggan, ditambah imbuhan agree yang berarti melakukan sesuatu berkali-kali dengan menggunakan tanggan-tanggan. ${ }^{6}$

Dalam dunia pendidikan juga tidak lepas dari konsep-konsep "manajemen pendidikan". Kemudian apalagi kita ingin mendefinisikan secara sederhana manajemen pendidikan dapat diartikan sebuah konsep manajemen yang diterapkan dalam dunia pendidikan dengan spesifikasi dan ciri khas tertentu sesuai dengan apa yang ada dalam pendidikan. Manajemen pendidikan bukanlah objek bahasa dalam praktik pendidikan namun pada dasarnya efektif dan efisien. Sehingga dapat produktivitas lembaga pendidikan.

${ }^{6}$ Didin Kurniadin dan Imam Machalin, Manajemen Pendidikan Konsep dan Prinsip Pengelolaan Pendidikan (Jogjakarta: AR-RUZZ MEDIA. 2012) h. 23 
Manajemen sering diartikan sebagai ilmu, kiat, dan profesi. Dikatakan sebagai ilmu oleh Luther Gulick karena manajemen dipandang sebagai suatu bidang pengetahuan yang secara sistematik berusaha memahami mengapa dan bagaimana orang bekerja sama. Dikatakan sebagai kiat oleh Follet karena manajemen mencapai sasaran melalui cara-cara dengan mengatur orang lain menjalankan dalam tugas. Dipandang sebagai profesi karena manajemen dilandasai oleh keahlian khusus untuk mencapai suatu prestasi manajer, dan para professional dituntun oleh suatu kode etik ${ }^{7}$

\section{Prinsip-Prinsip Manajemen Pendidikan}

Dalam kaitan dengan prinsip dasar manajemen, Fayol mengemukakan sejumlah prinsip, yaitu: pembagian kerja, kejelasan dalam wewenang dan tanggung jawab, disiplin, kesatuan komando, kesatuan Arah lebih memprioritaskan kepentingan umum/organisasi dari pada kepentingan pridadi pemberian konrak prestasi, sentralisasi, rantai scalat, tertib, pemerantakan, stabilitas dalam menjabat, inisiatif, dan semagat kelompok. ${ }^{8}$

Douglas merumuskan prinsip-prisip manajemen pendidikan sebagai berikut :

a. Memprioritaskan tujuan di atas kepentingan pribadi dan kepentingan golongan.

b. Mengkoordinasikan wewenang dan tanggung jawab.

\footnotetext{
${ }^{7}$ Nanang Fattah, Landasan Manajemen Pendidikan (Cet. 10; Bandung, 2009), h. 1

${ }^{8}$ Mujamil Qomar, Manajemen Pendidikan Islam (Erlangga, 2007), h. 10
} 
c. Memberikan tanggung jawab pada personil sekolah hendaknya sesuai dengan sifat-sifat dan kemampuannya.

d. Mengenal secara baik faktor-faktor psikologis manusia.

e. Relatifitas nilai-nilai ${ }^{9}$

Dari prinsip di atas memiliki esensi bahwa manajmemen dalam ilmu dan praktinya harus memperhatikan tujuan, orang-orang tugas-tugas, dan nilai-nilai.

\section{Fungsi Manajemen Pendidikan}

Untuk mempermudah pembahasan mengenai fungsi manajemen, secara garis besar fungsi-fungsi manajemen pendidikan meliputu: Perencanaan (planning), pengorganisasian (organizing), pengarahan/kepemimpinan (directing/leadership), dan pengawasan (controlling).

Perencanaan adalah sebuah proses perdana ketika hendak melakukan pekerjaan baik dalam bentuk pemikiran maupun kerangka kerja agar tujuan yang hendak dicapai mendapatkan hasil yang optimal. Demikian pula halnya dalam pendidikan Islam perencanaan harus dijadikan langkah pertama yang benar-benar diperhatikan oleh para manajer dan para pengelola pendidikan Islam. Sebab perencanaan merupakan bagian penting dari sebuah

${ }^{9}$ Nugraha Suharto, Manajemen Pendidikan (Cet; VI, Bandung: Alfabeta 2013), h. 
kesuksesan, kesalahan dalam menentukan perencanaan pendidikan Islam akan berakibat sangat patal bagi keberlangsungan pendidikan Islam. ${ }^{10}$

Ajaran Islam senantiasa mendorong para pemeluknya untuk melakukan segala sesuatu secara terorganisir dengan rapi, sebab bisa jadi suatu kebenaran yang tidak terorganisir dengan rapi akan dengan mudah bisa diluluhlantakan oleh kebathilan yang tersusun rapi. ${ }^{11}$

Sebuah organisasi dalam manajemen pendidikan Islam akan dapat berjalan dengan lancar dan sesuai dengan tujuan jika konsisten dengan prinsip-prinsip yang mendesain perjalanan organisasi yaitu kebebasan, keadilan, dan musyawarah. Jika kesemua prinsip ini dapat diaplikasikan secara konsisten dalam proses pengelolaan lembaga pendidikan Islam akan sangat membantu bagi para manajer pendidikan Islam. ${ }^{12}$

Pengorganisasian terjadi karena pekerjaan yang perlu dilaksanakan itu terlalu berat untuk ditangani oleh satu orang saja. Dengan demikian, diperlukan tenaga-tenaga bantuan dan terbentuklah suatu kelompok kerja yang efektif. Banyak pikiran, tangan, dan keterampilan dihimpun menjadi satu yang harus dikoordinasi bukan saja untuk diselesaikan tugas-tugas yang bersangkutan, tetapi juga untuk menciptakan kegunaan bagi masing-masing anggota kelompok tersebut terhadap keinginan keterampilan dan pengetahuan. ${ }^{13}$

\footnotetext{
${ }^{10}$ Iwan Sukiswa, Dasar-Dasar Umum Manajemen Pendidikan, (Bandung: Tarsito 1986), h. 79

${ }^{11}$ M. Manulang, Dasar-Dasar Manajemen (Jakarta: Ghalia Indonesia,1963), h. 89

${ }^{12}$ Mulyono, Manajemen Administrasi dan Organisasi Pendidikan (Cet. I Yokyakarta: Ar- Ruzz Media, 2008), h.71

${ }^{13}$ M. Manulang, Dasar-Dasar Manajemen, (Jakarta: Ghalia Indonesia,1963), h. 96
} 
Pengarahan adalah proses memberikan bimbingan kepada rekan kerja sehingga mereka menjadi pegawai yang berpengetahuan dan akan bekerja efektif menuju sasaran yang telah ditetapkan sebelumnya.

Dengan demikian dapatlah disimpulkan bahwa fungsi pengarahan dalam manajemen pendidikan Islam adalah proses bimbingan yang didasari prinsip-prinsip religius kepada rekan kerja, sehingga orang tersebut mau melaksanakan tugasnya dengan sungguh- sungguh dan bersemangat disertai keikhlasan yang sangat mendalam. ${ }^{14}$

Pengawasan adalah keseluruhan upaya pengamatan pelaksanaan kegiatan operasional guna menjamin bahwa kegiatan tersebut sesuai dengan rencana yang telah ditetapkan sebelumnya.

\section{B. Visi Sekolah dan Upaya Mewujudkannya Melalui Penerapan Manajemen Pendidikan}

Internalisasi visi sangat esensial bagi orang-orang yang menjalankan fungsi kepemimpinan, terutama bagi mereka yang menduduki posisi puncak, seperti rektor, dekan, dan pejabat tinggi kependidikan ditingkat departemn. Kepala sekolah pun, meski berada pada tingkat mikro, harus memiliki visi yang jelas. Dalam kaitan ini, kontter berpendapat bahwa visi merupakan komponen sentral dari semua great leadership. Termonologi great leadership merujuk pada 2 hal. Pertama adalah orang-orang yang duduk pada posisi pimpinan yang benar-benar piawai dalam menjalankan tugas

\footnotetext{
${ }^{14}$ M. Manulang, Dasar-Dasar Manajemen, (Jakarta: Ghalia Indonesia,1963), h. 97
} 
pokok dan fungsinya untuk mencapai tujuan organisasi secara efektif,efisien,dan dengan akuntabilitas tertentu. Kedua adalah posisi-posisi strategis yang diduduki oleh manusia organisasional, seperti eksekutif puncak, rektor perguruan tinggi, direntuk akademik, direntor dan sebuah direktorat, dan pejabat tinggi negara.

Visi adalah suatu inovasi di dalam dunia manajemen modern, terutama manajemen strategik. Istilah strategik ini merujuk pada posisi pimpinan puncak sebuah organisasi, termasuk organisasi pendidikan, juga sekolah. Gaffar berpendapat bahwa visi dipandang sebagai suatu inovasi dalam proses manajemen strategik karena baru pada akhir-akhir ini bisa disadari dan ditemukan bahwa visi itu amat dominan perannya dalam proses pembuatan keputusan, termasuk dalam setiap pembuatan kebijakan dan penyusunan strategi. ${ }^{15}$.

\section{a. Merumuskan Visi}

Visi merupakan gambaran tentang masa depan (future) yang realistik dan ingin diwujudkan dalam kurun waktu tertentu. Visi adalah pernyataan yang diucapkan atau ditulis hari ini, yang merupakan proses manajemen saat ini yang menjangkau masa yang akan datang. ${ }^{16}$

Bagi sekolah Visi adalah imajinasi moral yang menggambarkan profil sekolah yang diinginkan di masa datang. Imajinasi ke depan seperti itu

\footnotetext{
${ }^{15}$ Sudarwan Danim, Visi Baru Manajemen Sekolah: Dari Unit Birokrasi ke Lembaga Akademik (Cet. III; Jakarta: Bumi Aksara, 2008), h. 71

${ }^{16}$ Akdon, Strategic Managemen for Educational Management (Bandung: Alfabeta, 2006), h. 95
} 
akan selalu diwarnai oleh peluang dan tantangan yang diyakini akan terjadi di masa datang. Dalam menentukan visi tersebut, sekolah harus memperhatikan perkembangan dan tantangan masa depan.

Menurut Akdon, terdapaat beberapa kriteri dalam merumuskan visi, antara lain:

1) Visi bukanlah fakta, tetapi gambaran pandangan ideal masa depan yang ingin diwujudkan.

2) Visi dapat memberikan arahan, mendorong anggota organisasi untuk menunjukkan kinerja yang baik.

3) Dapat menimbulkan inspirasi dan siap menghadapi tantangan.

4) Menjembatani masa kini dan masa yang akan datang.

5) Gambaran yang realistik dan kredibel dengan masa depan yang menarik.

6) Sifatnya tidak statis dan tidak untuk selamanya ${ }^{17}$

\section{b. Upaya Mewujudkan Visi Sekolah}

Untuk mewujudkan visi sekolah, guru harus siap dan memahami makna dan langkah-langkah pencapaiannya, guru juga harus mampu mengintegrasikan indikator pencapaian visi sekolah ke dalam rencana pelaksanaan pembelajaran (RPP). Pengintegrasian indikator ke PBM-lah yang selalu dilupakan oleh guru padahal keberhasilan mewujudkan visi sekolah bergantung pada proses belajar mengajar yang dilaksanakan oleh guru.

\footnotetext{
${ }^{17}$ Akdon, Strategic Managemen for Educational Management, h. 96
} 
Akibatnya, visi yang sedianya menjadi pengarah semua aktivitas di sekolah menjadi tidak berarti bahkan hanya sebagai simbol semata. Guru terlalu fokus kepada kemauan kurikulum tanpa melakukan inovasi-inovasi pembelajaran. Faktor inilah yang membuat output yang dihasilkan oleh sekolah jauh dari karakter yang diharapkan sebagaimana yang dijabarkan oleh visi sekolah. Berikut beberapa hal yang harus dilakukan untuk mewujudkan visi sekolah.

1. Pengintegrasian indikator visi ke dalam proses belajar mengajar yang dilakukan oleh guru.

2. Program-program yang direncanakan harus mengarah kepada pencapaian indikator visi sekolah.

3. Pemanfaatan budaya lokal untuk pengembangan diri.

4. Merancang langkah-langkah kreatif yang dapat merubah sikap dan prilaku siswa.

5. Pemberdayaan kegiatan ekstrakurikuler.

6. Bekerjasama siswa dalam membuat proyek-proyek pembelajaran.

7. Mengoptimalkan kewenangan kepala sekolah dalam mendukung MBS.

8. Mengoptimalkan semua potensi yang ada disekolah.

9. Pemberdayaan guru.

10. Transparansi, akuntabilitas, dan efektifitas. ${ }^{18}$

\section{Metode Penelitian} 2006), h. 97

${ }^{18}$ Akdon: Strategic Managemen for Educational Management (Bandung: Alfabeta 
Sebagaimana diketahui bahwa setiap karya tulis ilmiah berbasis penelitian pada prinsipnya selalu ditopang oleh beberapa metode, baik dalam pengumpulan data maupun dalam pengolahannya. Seperti halnya dalam penyusunan draft skripsi ini dipergunakan metode sebagai berikut:

\section{Jenis dan Pendekatan Penelitian}

Adapun jenis penelitian yang akan peneliti gunakan dalam penelitian ini adalah penelitian kualitatif. Penelitian dekriptif kualitatif (Qualitatif Research) adalah suatu penelitian yang ditujukan untuk mendeskripsikan dan menganalisis fenomena, peristiwa, aktivitas sosial, sikap, kepercayaan, persepsi, pemikiran orang secara individual maupun kelompok. ${ }^{19}$

Adapun pendekatan penelitian yang dipergunakan dalam penulisan skripsi ini adalah:

\section{a. Pendekatan paedagogis}

Paedagogis artinya ilmu pendidikan yang menyelidiki, menerangkan tentang gejala-gejala perbuatan mendidik atau dengan kata lain paedagogis sebagai suatu ilmu yang memberikan landasan, pedoman dan arah sasaran dalam usaha mendidik atau membentuk peserta didik menjadi manusia yang beradab yaitu manusia yang berilmu pengetahuan, keterampilan, bermasyarakat, berbudaya, dan berakhlak

\footnotetext{
${ }^{19}$ Nana Syaodih Sukmandinata, Metode Penelitian Pendidikan (Cet. I; Bandung: Remaja Rosdakarya, 2005), h. 60
} 
atau berbudi pekerti yang luhur, sehingga pendekatan ini penting dalam penulisan skripsi ini. ${ }^{20}$

\section{b. Pendekatan sosiologis}

Pendekatan sosiologis adalah ilmu yang mempelajari hidup bersama dalam masyarakat, dan menyelidiki ikatan-ikatan antara manusia yang menguasai hidupnya itu. ${ }^{21}$ Oleh karena itu, pendekatan sosiologis perlu karena dalam penelitian ini penulis akan banyak berinteraksi dengan masyarakat sekolah, baik itu tenaga pendidik maupun tenaga kependidikan untuk lebih mudah mendapatkan informasi yang dibutuhkan.

\section{Lokasi Penelitian}

Penelitian ini berlangsung di SMP Negeri 1 Salomekko yang merupakan lembaga pendidikan formal tingkat menengah pertama yang terletak di Jl. Poros Bone Sinjai Kab. Bone, Provinsi Sulawesi Selatan.

\section{Data dan Sumber Data}

Jenis data yang diperlukan dalam penelitian ini meliputi data primer dan data sekunder. Kedua data tersebut didapatkan melalui sumber tertentu, yakni:

a. Data Primer

${ }^{20}$ Abuddin Nata, Metodologi Studi Islam, (Cet. VIII; Jakarta: Raja Grafindo Persada, 2003), h. 49

${ }^{21}$ Sugiono, Metode Penelitian Kuantitatif, Kualitatif dan Kombinasi, (Cet. I; Bandung: Alfabeta, 2011), h. 34 
Data primer adalah data yang diperoleh langsung pada subyek sebagai sumber informasi yang ingin dicapai. ${ }^{22}$ Data primer dalam penelitian ini diperoleh langsung dari lokasi penelitian yaitu melalui observasi dan wawancara. Adapun sumber data primer penelitian ini yaitu kepala sekolah dan guru.

b. Data Sekunder

Data sekunder adalah data yang diperoleh dari pihak lain, yakni tidak langsung diperoleh oleh peneliti dari subjek penelitiannya. Atau data sekunder adalah jenis data yang diperoleh melalui hasil pengolahan pihak kedua dari hasil penelitian lapangannya. ${ }^{23}$ Data sekunder berasal dari dokumen dan bahan pustaka.

\section{HASIL PENELITIAN}

\section{A. Penerapan manajamen pendidikan di SMPN 1 Salomekko Kab, Bone}

Pengorganisasian adalah aktivitas penyusunan, pembentukan hubungan kerja antara orang-orang sehingga terwujud suatu kesatuan usaha dalam mencapai tujuan yang telah ditentukan. Akitivitas mengumpulkan segala tenaga untuk membentuk suatu kekuatan baru dalam rangka mencapai tujuan merupakan kegiatan dalam manajemen, karena pada dasarnya mengatur segala sesuatu yang ada dalam sebuah organisasi maupun suatu lembaga adalah kegiatan pengorganisasian. Kegiatan menyusun berbagai

${ }^{22}$ Abdullah K, Tahapan dan Langkah-Langkah Penelitian (Cet. I; Watampone, Luqman al-Hakim Press, 2013), h. 41

${ }^{23}$ Burhan Bungin, Metode Penelitian Kualitatif, (Cet. 8; Jakarta: Raja Grafindo, 2011), h. 155 
elemen dalam sebuah lembaga pendidikan maupun instansi merupakan kegiatan manajemen yang secara khusus disebut sebagai pengorganisasian, hal ini makin memperjelas bahwa di antara fungsi manajemen adalah menyusun dan membentuk berbagai hubungan kerja dari berbagai unit untuk menjadi sebuah tim yang solid, dari tim yang solid akan memberi kekuatan. Apabila terjadi kesatuan kekuatan dari berbagai elemen sistem untuk mencapai tujuan dalam lembaga maupun organisasi maka manajemen dianggap berhasil. ${ }^{24}$

Andi Jamila, S.S. Mengatakan bahwa cara menerapanya yaitu melakakun kegiatan pada tiap-tiap unit kerja supaya dapat terorganisir ke arah tujuan yang sama mengalokasikan sumber daya menyusun serta menerapkan dan sekolmpok orang yang diarahkan untuk bekerja sama daya menyusun serta menerapkan dan sekelompok orang yang diarahkan untuk bekerja sama agar perencanaan, pengorganisasi pelaksaan dan pengawasan yang bisa diterapkan. ${ }^{25}$

Rosmini, S.Pd. berpendapat bahwa memberikan keluasan kepada masing-masing satuan pendidikan, dengan memberikan otonimi yang luas dengan melibatkan siswa dalam rangka mengfektifkan proses pembelajaran pada perencanaan, pengorganisasian serta pengawasan tersebuat. $^{26}$

Manajemen pendidikan berkaitan erat dengan penerapan hasil berpikir rasional untuk mengorganisasikan kegiatan yang menunjang pembelajaran. Kegiatan-kegiatan yang berkaitan erat dengan pembelajaran perlu direncanakan dan dikelola dengan sebaik mungkin. Untuk

${ }^{24}$ Asnawir, Manajemen Pendidikan, Padang: IAIN IB Press, 2006

${ }^{25}$ Andi Jamila, Guru SMP Negeri 1 Salomekko, "wawancara" pada tanggal 2017 di Watampone

${ }^{26}$ Rosmini,Guru SMP Negeri 1 Salomekko, "wawancara" pada tanggal 2017 di Watampone 
merencanakan dan mengelola agar bisa mencapai tujuan yang diharapkan, seorang manager harus mempunyai kemampuan konseptual (conseptual skill), kemampuan teknis (technical skill), dan hubungan insani (human skill).

Manajemen pendidikan meletakkan kajian pada berbagai unsur manajemen yang bertujuan untuk mencapai tujuan pendidikan secara efektif dan efisien. Tujuan pendidikan berkaitan erat dengan tujuan intruksional, kurikuler, institusional hingga pada tujuan nasional yang diatur oleh undangundang No 20 tahun 2003. Oleh karena itu, manajemen personalia, kesiswaan, kurikulum, dan pembelajaran merupakan substansi manajemen pendidikan yang harus mendapatkan perhatian yang lebih supaya pendidikan bisa dicapai secara maksimal (efektif dan efisien).

Andi Jamila, S.S. Mengatakan bahwa mengatur segala kegiatan yang ada di sekolah sesuai dengan prosedur yang ada di sekolah tersebut membuat perencanaan yang baik dan melibatkan seluruh warga sekolah memudahkan atau mengatur administrasi dalam berbagai kegiatan sekolah. ${ }^{27}$

Rosmini, S.Pd. berpendapat bahwa dengan meningkatkan mutu pendidikan melalui kemandirian dan iniseatif satuan pendidikan sekolah dalam mengembangkan kurikulum pengelolan dan memberdayakan sumber daya yang tersedia, menigkatkan kepedulian sekolah dalam mengembangkan kurikulm melalui pengambilan keputusan secara bersama (kolektif). ${ }^{28}$

Pendidikan yang bermutu adalah pendidikan yang menghasilkan lulusan yang memiliki kemampuan atau kompetensi. Baik kompetensi akademik maupun kompetensi kejuruan, yang dilandasi oleh kompetensi

${ }^{27}$ Andi Jamila, Guru SMP Negeri 1 Salomekko, "wawancara" pada tanggal 2017 di Watampone

${ }^{28}$ Rosmini, Guru SMP Negeri 1 Salomekko, "wawancara" pada tanggal 2017 di Watampone 
personal dan sosial, yang secara menyeluruh disebut sebagai kecakapan hidup (life skill). Pendidikan kecakapan hidup adalah pendidikan bermutu, baik quality in fact maupun quality in perception (Sudrajat, 2005: 17). Untuk dapat meningkatkan mutu pendidikan, madrasah harus dapat melaksanakan pengelolaan yang didasarkan pada peningkatan mutu pendidikan sekolah.

Andi Jamila, S.S. mengatakan bahwa untuk mencapai suatu pembelajaran yang bermutu penerapan dalam pendidikan di sekolah adalah dengan mengadakan pelajaran tambahan seperti mengadakan les sore dan tri out setiap hari pada saat memasuki ujian nasional supaya siswa bisa lulus cerdas, terampil, berkarakter, beriman, dan bertakwa.

Pendapat Rosmini, S.Pd. mengatakan bahwa memberikan bimbingan diluar dari sekolah supaya seorang siswa melakukan proses belajar mengajar setiap hari, membentuk organisasi semacan sangar seni supaya sorang siswa bisa menampilkan bakat dan kempuan dalam berkarkter dan terampil serta setiap hari jumat.

Manajemen Sarana dan Prasarana Pendidikan dapat didefinisikan sebagai proses kerjasama dalam melaksanakan pendayagunaan semua sarana dan prasarana yang ada di lembaga pendidikan secara efisien dan efektif.

\section{B. Penerapan manajemen pendidikan dalam mewujudkan visi sekolah}

Kepala sekolah/madrasah dituntut mempunyai kompetensi profesional sebagai pemimpin dan manajer di sekolah supaya dapat melaksanakan tugas dan tanggung jawabnya yang berkaitan dengan kepemimpinan pendidikan dengan sebaik mungkin termasuk di dalamnya sebagai pemimpin pengajaran. Selain itu juga agar kepala sekolah dapat melaksanakan tugas kepemimpinannya dengan seefektif mungkin untuk 
mewujudkan visi, misi dan tujuan yang diemban dalam mengoperasikan sekolah.

Andi Jamila, S.S. Mengemukakan bahwa cara mewujudkan visi sekolah adalah harus mengadakan dulu rapat terlebih dahulu bersama seluruh stekolder pemimpin, guru dan staf komite sekolah agar visi sekolah bias mengarahkan pada perkembangan proses pembelajaran dan perkembangan teknologi agar menghailkan agar siswa yang terdidik berkarakter beriman dan bertakwa.

Senada dengan Dra, Muhaena, bahwa cara mewujudka visi sekolah adalah harus mengadakan dulu rapat terlebih dahulu bersama seluruh stekolder pemimpin, guru dan staf komite sekolah agar visi sekolah bias mengarahkan pada perkembangan proses pembelajaran dan perkembangan teknologi agar menghasilkan siswa yang terdidik berkarakter beriman dan bertakwa.

Sedangkan Rosmini, S.Pd. Mengatakan bahwa kita harus melihat meningkatkan kemampuan siswa supaya proses belajar mengajar lebih efektif dalam berbicara serta bisa memberikan prestasi yang lebih baik serta dapat dapat mewujudkan ketakwaan dan keimanan siswa kepada guru dan sesama pelajar.

Pengorganisasian dalam manajemen pendidikan Islam adalah penentuan struktur, aktifitas, interaksi, koordinasi, desain struktur, wewenang, tugas secara transparan, dan jelas dalam lemabaga pendidikan baik bersifat individual, kelompok maupun kelembagaan. Dengan demikian, pengorganisasian dalam manajemen pendidikan Islam merupakan penetapan berbagai hal untuk mempermudah dalam aktivitas perwujudan perencanaan yang telah dibuat sebelumnya. Penetapan tersebut bukan hanya sekedar 
pembagian tugas, tetapi penetapan menyeluruh tentang segala sesuatu yang

membangun sistem tersebut, sehingga membentuk tim kerja yang akan mewujudkan tujuan pendidikan Islam.

Rosmini, S.Pd. Mengatakan karena dengan kemandirian dari profesionalisme kepada sekolah merupankan salah satu fatktor untuk dapat mendorong sekolah untuk mewujdukan visi dan misinya, oleh karena dalam merapakan suatu kurikulum yang diperlukan kepala sekolah yang tegas, profesional dengan kempuan manajemen dan kepemimpinan yang tangguh agar mampu mengambil keputusan dan prakarsa untuk meningkatkan mutu sekolah

Sedangan Andi Jamila, S.S. konstribusi penerapan menejemen pendidikan di sekolah dalam mewujudka, visi sekolah yaitu buku, komputer, alat-alat olahraga, radio dan alat shalat, di sekolah SMP NEGERI 1 Salomekko sudah mengalami peningkatan dari tahun ke tahun karena setiap tahun melakukan ujinan nasional dan menjuarai juara 1 sekabupaten Bone, dan cara meningkatkannya yaitu mengadakan tri out 3 kali, les sore, agar siswa bisa menyelesaikan ujian nasional dengan mudah.

penerapan menejemen di sekolah ini sudah berjalan dengan baik sesuai yang diharapka di sekolah ini.

cara pelaksanaan penerapan sekolah yaitu mengadakan rapat kerja menghadirkan semua guru-guru atau staf pegawai sekolah dalam mewujudkan visi sekolah. Kendala yang dihadapi faktor lingkungan dan kedisiplinan.

\section{DARTAR RUJUKAN}

Abbas M.S, Suyanto. Wajah dan Dinamika Pendidikan Anak Bangsa, Cet.I; Yogyakarta : 2001.

Akdon, Strategic. Managemen for Educational Management. Cet.I; Bandung: Alfabeta 2006. 
Arikunto Suharsimi. Prosedur Penelitian Suatu Pendekatan Praktik, Yogyakarta: Rineka Cipta, 1993.

Arikunto, Suharsimi. Prosedur Penelitian, Suatu Pendekatan Praktik Cet. XIII; Jakarta: Rineka Cipta, 2006.

Bungin, Burhan. Metode Penelitian Kualitatif, Cet.VIII; Jakarta: Raja 2011.

Daryanto. Kamus Bahasa Indonesia Lengkap Cet 1; Surabaya: Apolo, 1997.

Departemen Pendidikan Nasional, Kamus Besar Bahasa Indonesia, Edisi Ketiga Jakarta : Balai Pustaka, 2002.

Hadi Sutrisno. Metodologi Research, Jilid I, Yogyakarta: Andi Offset, 2001.

Hartani Bar. Manajemen Pendidikan, Cet. I; Yogyakarta: Laksibang Pressindo. 2011.

K, Abdullah. Tahapan dan Langkah-Langkah Penelitian, Cet. I; Watampone, Luqman al-Hakim Press 2013.

M John, Bryson. Perencanaan Strategis Bagi Organisasi Sosial. Yogyakarta: Pustaka Pelajar. 2001.

Masrokan Mutahor, Prim Mutahor. Manajemen Mutu Sekolah Jogyakarta Ar-ruzz Media, 2013 